\title{
Expression of cyclooxygenase 1 and 2 by human gastric endothelial cells
}

\author{
M A Hull, J L Thomson, C J Hawkey
}

\begin{abstract}
Background-Non-steroidal anti-inflammatory drugs (NSAIDs) inhibit cyclooxygenase (COX) and cause gastric ulceration. NSAIDs also impair granulation tissue angiogenesis and healing of established gastric ulcers in humans. The mechanism whereby NSAIDs inhibit granulation tissue angiogenesis is unknown but may involve inhibition of either or both COX isoforms (COX-1 and COX2).

Aims-To investigate COX expression by human gastric endothelial (HuGE) cells during angiogenesis in vitro.

Methods-COX-1 and COX-2 expression by HuGE cells was investigated by western blot analysis, indirect immunofluorescence, reverse transcriptase polymerase chain reaction, and measurement of prostaglandin $E_{2}$ synthesis. Plating onto basement membrane matrix and stimulation by phorbol ester were used as in vitro models of angiogenesis.

Results-Under normal culture conditions (30\% serum), HuGE cells expressed COX-1 and low levels of COX-2 . COX-2 expression was induced in $\mathrm{HuGE}$ cells in both angiogenesis models. Prostaglandin $E_{2}$ production and tubular structure formation by HuGE cells on basement membrane matrix was significantly inhibited by a selective COX-2 inhibitor (NS-398). Conclusion-Angiogenesis by HuGE cells in vitro was associated with induction of functional COX-2 expression. A selective COX-2 inhibitor significantly decreased HuGE cell angiogenesis on basement membrane matrix. Extrapolation of these data to human gastric ulcer angiogenesis in vivo suggests that selective COX-2 inhibitors could delay gastric ulcer healing to the same extent as traditional NSAIDs which are non-selective COX inhibitors.

(Gut 1999;45:529-536)
\end{abstract}

Keywords: angiogenesis; cyclooxygenase; endothelial cell; gastric mucosa; gastric ulcer; prostaglandins

Prostaglandins (PGs) are believed to play an important role in maintenance of human gastric mucosal homoeostasis. ${ }^{1}$ Inhibition of endogenous gastric mucosal PG synthesis by non-steroidal anti-inflammatory drugs (NSAIDs) is thought to underlie the ulcerogenic activity of such drugs and administration of exogenous PGs protects gastric mucosa from a variety of insults in animal models. ${ }^{2}$
Misoprostol (a $\mathrm{PGE}_{1}$ analogue) prevents NSAID associated peptic ulceration and its complications in humans. ${ }^{3}$

PGs are synthesised from arachidonic acid by cyclooxygenase (COX) via the unstable prostaglandin intermediate $\mathrm{PGH}_{2}$, which, in turn, is converted into other PG species such as $\mathrm{PGE}_{2}$ by the action of specific PG synthases, for example, $\mathrm{PGE}_{2}$ synthase. Two isoforms of COX are known to exist, namely a constitutive isoform, COX-1, and a mitogen inducible isoform, COX-2. ${ }^{4}$ Current dogma is that COX-1 is responsible for PG synthesis in normal gastric mucosa in order to maintain mucosal homoeostasis ${ }^{5}$ and that COX-2 is expressed by normal gastric mucosa at low levels, ${ }^{6}$ with induction of expression during ulcer healing ${ }^{78}$ or following endotoxin exposure. ${ }^{9}$ Iseki has reported the localisation of COX-1 and COX-2 to mucous cells of normal rat gastric mucosa ${ }^{10}$ but these data have not been confirmed by others who have been unable to detect COX-2 immunoreactivity in normal rat stomach. ${ }^{8911}$ There are no published studies of COX localisation in human gastric mucosa.

Gastric microvascular endothelial cells are a possible important source of human gastric mucosal PGs. Capillary endothelial cells are a major site of $\mathrm{PGE}_{2}$ production in canine fundic mucosa ${ }^{12}$ and COX-1 has been localised to endothelium of submucosal blood vessels in rat gastric mucosa. ${ }^{11}$ Furthermore, cultured human gastric endothelial (HuGE) cells synthesise $\mathrm{PGE}_{2}$ and $\mathrm{PGI}_{2}$ in vitro. ${ }^{13}$ It is established that human umbilical vein endothelial cells (HUVECs) express COX-1 constitutively and COX-2 following induction by factors such as interleukin 1 and phorbol ester in vitro. ${ }^{14-17}$ However, data from endothelial cells derived from large vessels such as the umbilical vein cannot necessarily be extrapolated to microvessel endothelial cells such as HuGE cells because endothelial cell function, for example, PG synthesis and cytokine production varies depending on the blood vessel(s) of origin. ${ }^{1318} 19$ Therefore, we investigated COX-1 and COX-2 expression by HuGE cells in vitro.

It has recently been shown that healing of acetic acid induced gastric ulcers in mice is associated with induction of COX-2 expression $^{7}$ and that COX-2 is localised to

Abbreviations used in this paper: COX, cyclooxygenase; ECGS, endothelial cell growth supplement; HuGE, human gastric endothelial; HUVEC, human umbilical vein endothelial cell; NSAID, non-steroidal anti-inflammatory drug; PG, prostaglandin; PKC, protein kinase C; PdBu, phorbol 12,13-dibutyrate. 
endothelial cells in granulation tissue of cryoprobe induced gastric ulcers in rats. ${ }^{8}$ NSAIDs (which are COX inhibitors) reduce gastric ulcer granulation tissue angiogenesis ${ }^{20}$ and delay gastric ulcer healing in humans ${ }^{21}$ and animals. ${ }^{22}$ Therefore, we investigated HuGE cell COX expression and the effect of selective COX-2 inhibition during angiogenesis in vitro.

\section{Methods}

ISOLATION AND CULTURE OF HUMAN GASTRIC ENDOTHELIAL (HuGE) CELLS

Human gastric endothelial (HuGE) cells were isolated from normal organ donor stomachs as described previously. ${ }^{13}$ Cells were routinely cultured on $1 \%$ gelatin in Medium 199 containing $1 \mathrm{mM}$ L-glutamine, $90 \mu \mathrm{g} / \mathrm{ml}$ heparin, $100 \mathrm{U} / \mathrm{ml}$ penicillin $\mathrm{G}, 100 \mu \mathrm{g} / \mathrm{ml}$ streptomycin, $250 \mathrm{ng} / \mathrm{ml}$ amphotericin B (all GIBCO BRL, Paisley, UK), $40 \mu \mathrm{g} / \mathrm{ml}$ endothelial cell growth supplement (ECGS; Advanced Protein Products, Brierley Hill, UK), and 30\% fetal calf serum at $37^{\circ} \mathrm{C}$ in $5 \% \quad \mathrm{CO}_{2}$. The endothelial nature of cell monolayers was confirmed regularly by indirect immunofluorescence for PECAM-1. ${ }^{13} \mathrm{HuGE}$ cells were used up to passage 18 .

HUVECs were isolated according to the method of Jaffe et $a l^{23}$ and cultured as above except that fetal calf serum was added to the culture medium at $20 \% \mathrm{vol} / \mathrm{vol}$.

IN VITRO ANGIOGENESIS MODELS

Plating on basement membrane matrix

(Matrigel)

Cells were plated onto a thin layer of basement membrane matrix (Matrigel, Becton Dickinson, Bedford, Massachusetts, USA) ${ }^{24}$ in six well plates at $2 \times 10^{5}$ cells/well in Medium 199 containing $1 \mathrm{mM}$ L-glutamine, $90 \mu \mathrm{g} / \mathrm{ml}$ heparin, and $30 \%$ fetal calf serum and incubated at $37^{\circ} \mathrm{C}$ in $5 \% \mathrm{CO}_{2}$ for up to 24 hours. At four or 24 hours cells were removed from basement membrane matrix by incubation with $50 \mathrm{U} / \mathrm{ml}$ dispase (Becton Dickinson) for 60 minutes at $37^{\circ} \mathrm{C}$. Dispase activity was neutralised by dilution $(\times 5)$ in Hanks's balanced salt solution without calcium and magnesium (GIBCO BRL) and cells were collected by centrifugation. The number of viable cells obtained at the end of experiments was counted using a haemocytometer and exclusion of $0.2 \%$ Trypan blue (Sigma, Poole, UK).

Quantification of the degree of tubular structure formation by $\mathrm{HuGE}$ cells at four and 24 hours was performed by counting the number of complete circles produced by interlinking, tubular HuGE cells. Photomicrographs of each quadrant of individual wells were obtained using an Olympus OK2 inverted microscope and an Olympus $\mathrm{OM}-1_{\mathrm{N}}$ camera with 200 ASA photographic film. A grid was superimposed on the photomicrographs using a custom made lens. The number of complete circles of interlinking, tubular HuGE cells with any part within the grid was counted in each quadrant by two independent observers blinded to the origin of the photomicrograph. The mean number of circles counted by both observers in each quadrant was used for further analysis.

\section{Phorbol ester stimulation}

Alternatively, cells were incubated with $1 \mu \mathrm{M}$ phorbol 12,13-dibutyrate (PdBu; Sigma) in $1 \%$ gelatin coated wells for up to 24 hours under the same conditions. Cell suspensions were obtained using $0.5 \%$ trypsin solution (GIBCO BRL) and viable cells counted as above.

REVERSE TRANSCRIPTASE POLYMERASE CHAIN REACTION (RT-PCR) AMPLIFICATION OF COX-1 AND COX-2 mRNA

Total RNA was extracted from cells using a guanidinium isothiocyanate-phenol:chloroform extraction technique ${ }^{25}$ followed by precipitation of RNA with isopropanol (Micro RNA Isolation Kit, Stratagene, La Jolla, California, USA). A $5 \mu \mathrm{g}$ aliquot of total RNA was reverse transcribed with $100 \mathrm{ng} / \mu \mathrm{l}$ oligo(dT) $)_{12-18}$ primers (Pharmacia Biotech Ltd, St Albans, UK), $200 \mathrm{nmol}$ dNTPs, 40 U ribonuclease inhibitor, and $50 \mathrm{U} \mathrm{M}-\mathrm{MuLV}$ reverse transcriptase (StrataScript RT-PCR kit, Stratagene). The reaction mix was incubated at $37^{\circ} \mathrm{C}$ for 60 minutes and then $90^{\circ} \mathrm{C}$ for five minutes. PCR was performed using specific primers (COX-1: forward, 5'-GAGTCTTTCTCCAAC GTGAGC-3', reverse, 5'-ACCTGGTACTTG AGTTTCCCA-3'; COX-2: forward, 5'-TGAA ACCCACTCCAAACACAG-3', reverse, 5'TCATCAGGCACAGGAGGAAG-3') at 20 $\mu \mathrm{M}$ in the presence of $0.8 \mathrm{mM} \mathrm{dNTPs}$ and 1.5 $\mathrm{mM} \mathrm{MgCl}$ in a Trio-Thermoblock TB- 1 thermocycler (Biometra, Gottingen, Germany). A $5 \mu \mathrm{l}$ aliquot of first strand product was heated to $91^{\circ} \mathrm{C}$ for five minutes and $2.5 \mathrm{U}$ DNA polymerase was added at the annealing temperature of $54^{\circ} \mathrm{C}$. PCR was carried out for 30 cycles as follows: $95^{\circ} \mathrm{C}$ for 45 seconds, $54^{\circ} \mathrm{C}$ for 90 seconds, $72^{\circ} \mathrm{C}$ for 90 seconds. Finally, the reaction was heated to $54^{\circ} \mathrm{C}$ for two minutes and then $72^{\circ} \mathrm{C}$ for three minutes. Glyceraldehyde-3-phosphate dehydrogenase $(\mathrm{GAPDH})$ primers (Stratagene) ${ }^{14}$ were used as a control at $1 \mu \mathrm{M}$. PCR products were separated on $1.2 \%$ agarose gels and stained with $0.5 \mu \mathrm{g} / \mathrm{ml}$ ethidium bromide. The size of PCR products was assessed by comparison with $2 \mu \mathrm{g} \phi \mathrm{X} 174 / \mathrm{Hae}$ III digest markers (Promega, Madison, Wisconsin, USA). In addition to being the predicted size, the nature of PCR products was confirmed by automated sequencing.

WESTERN BLOT ANALYSIS OF COX-1 AND COX-2 Polyclonal rabbit COX-1 antiserum and affinity purified polyclonal antihuman COX-2 immunoglobulin ${ }^{26-28}$ were obtained from Cayman Chemical Co. (Ann Arbor, Michigan, USA). To ensure specificity of anti-COX antibodies for their COX isoforms, western blotting was carried out using $500 \mathrm{ng}$ of ram seminal vesicle COX-1 and sheep placental COX-2 (both Cayman Chemical Co.) using standard methodology as described previously. ${ }^{29}$ Following overnight incubation with 1/500 dilutions of COX-1 and COX-2 
A

anti-COX-1

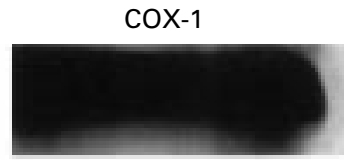

anti-COX-2

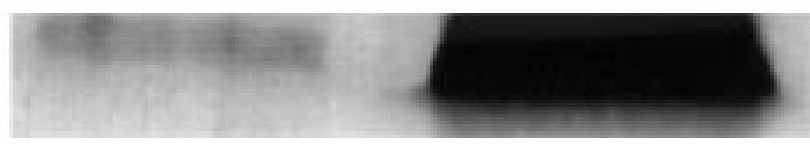

B
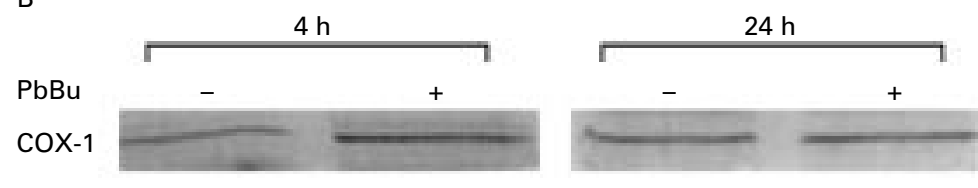

COX-2

Figure 1 Western blot analysis of (A) cyclooxygenase (COX) 1 and COX-2 standards $(500 \mathrm{ng})$ and (B) human gastric endothelial (HuGE) cell homogenates (50 $\mu \mathrm{g}$ total protein) at four and 24 hours with or without $1 \mu \mathrm{M}$ phorbol 12,13-dibutyrate (PdBu). COX-2 was not detectable in basal HuGE cells but there was induction of COX-2 expression by $\mathrm{PdBu}$ at four and 24 hours compared with control cells.

antibodies at $4^{\circ} \mathrm{C}$, membranes were incubated for 30 minutes at room temperature with biotinylated goat antirabbit $\operatorname{IgG}$ and developed using an ABC-peroxidase technique (both VECTASTAIN Elite ABC kit, Vector Laboratories, Burlingame, California, USA).

HuGE cells were washed with phosphate buffered saline (PBS) and removed using a cell scraper (Becton Dickinson). Cells were pelleted by low speed centrifugation and $50 \mu$ lysis buffer (10 mM PBS, $0.1 \%$ Triton-X-100, $0.01 \%$ EDTA, $1 \mathrm{mM}$ phenylmethylsulphonyl

A Basal HUVECs (-PdBu)

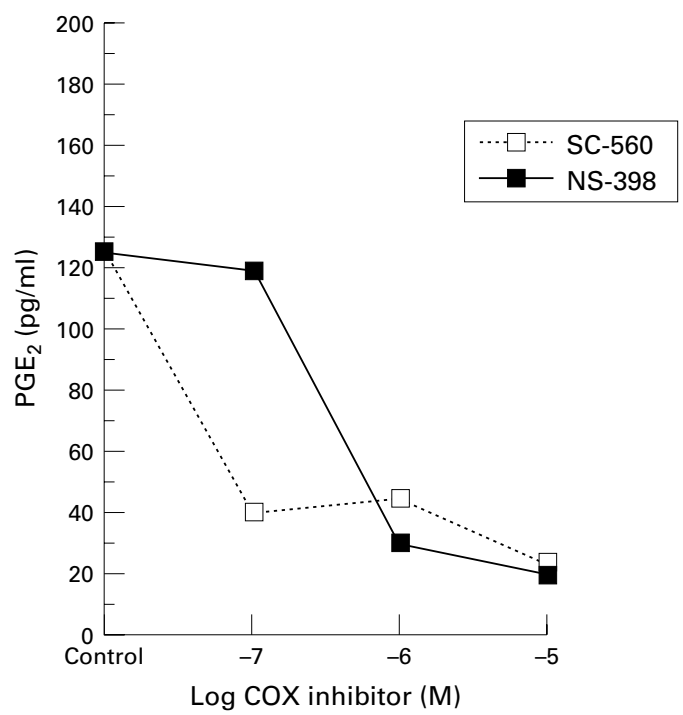

fluoride (PMSF), and $0.03 \%$ leupeptin) was added before boiling for three minutes. Cell lysates were centrifuged at $10000 \mathrm{~g}$ for 10 minutes and the supernatant obtained. Western blot analysis of equal amounts of total protein $(50 \mu \mathrm{g})$ was carried out as above.

\section{INDIRECT IMMUNOFLUORESCENCE}

CYTOCHEMISTRY FOR COX-1 AND COX-2

Cells grown on $1 \%$ gelatin coated coverslips were fixed in $100 \%$ methanol at $-30^{\circ} \mathrm{C}$ and indirect immunofluorescence studies performed as described previously. ${ }^{13} \mathrm{COX}-1$ and COX-2 antibodies were used at 1/50 dilutions. The goat antirabbit immunoglobulinfluorescein isothiocyanate conjugate (Sigma) was used at a 1/20 dilution. Omission of the primary antibody and incubation with either normal rabbit serum (Sigma) or rabbit immunoglobulin (Dako, High Wycombe, UK) at the same concentration as the respective primary antibody were used as controls.

COX INHIBITORS USED

The selective COX-2 inhibitor N-[2cyclohexyloxy-4-nitrophenyl] methanesulphonamide (NS-398) was obtained from Cayman Chemical Co. ${ }^{30}$ SC-560, a selective COX-1 inhibitor, ${ }^{31}$ was a kind gift from Searle Research and Development (St Louis, Missouri, USA). HUVECs were used in preliminary experiments to confirm that the concentrations of SC-560 and NS-398 used in HuGE cell experiments selectively inhibited COX isoforms. $\mathrm{PGE}_{2}$ synthesis by unstimulated HUVECs and by HUVECs after incubation with 1 $\mu \mathrm{M} \mathrm{PdBu}$ was used as a measure of COX -1 and COX-2 activity respectively as described previously. $^{32}$

B PdBu stimulated HUVECs

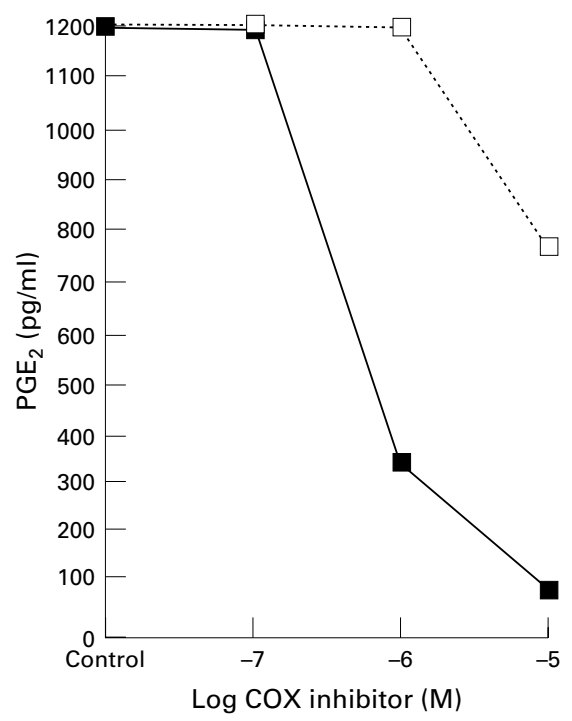

Figure 2 Inhibition of human umbilical vein endothelial cell (HUVEC) prostaglandin (PG) $E_{2}$ synthesis by selective cyclooxygenase (COX) inhibitors. PGE levels were measured at 24 hours in medium conditioned by (A) basal HUVECs (COX-1 activity) or (B) HUVECs stimulated by $1 \mu \mathrm{M}$ phorbol 12,13-dibutyrate (PdBu) (COX-2 activity). Differing concentrations of SC-560 or NS-398 were added with fresh medium at the start of experiments. Control experiments were performed in the absence of COX inhibitor. Data shown are the mean of duplicate experiments for each drug concentration. 
$1 \%$ gelatin

Basement membrane matrix

coX-1

$\mathrm{COX}-2$

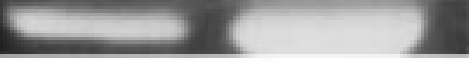

GAPDH

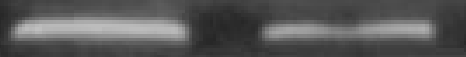

Figure 3 RT-PCR analysis of cyclooxygenase (COX) 1, $C O X-2$, and GAPDH $m R N A$ expression by human gastric endothelial (HuGE) cells 24 hours after plating onto were stained with $0.5 \mu \mathrm{g} / \mathrm{ml}$ ethidium bromide and visualised using an ultraviolet transilluminator. PCR products were the expected size: $C O X-1,350 \mathrm{bp} ; C O X-2$, $232 \mathrm{bp} ; \mathrm{GAPDH}, 600 \mathrm{bp}$. Formation of tubular structures by HuGE cells on basement membrane matrix was associated with increased COX-2 mRNA expression. Similar results were obtained at four hours after plating onto basement membrane matrix.

MEASUREMENT OF PGE 2 SYNTHESIS BY HUGE CELLS

Aliquots $(200 \mu \mathrm{l})$ of cell culture medium were removed at zero, four, and 24 hours, centrifuged at $2000 \mathrm{~g}$ for two minutes, and then assayed using a commercially available $\mathrm{PGE}_{2}$ competitive ELISA (Amersham, Little Chalfont, UK).

\section{Results}

SPECIFICITY OF THE COX ANTIBODIES

Western blot analysis of COX standards confirmed the specificity of the COX antibodies for their isoforms (fig 1A). There was slight cross reactivity of the COX-2 antibody with COX-1 protein. basement membrane matrix or $1 \%$ gelatin. PCR products

ESTABLISHING A SELECTIVE CONCENTRATION FOR THE COX INHIBITORS

$\mathrm{PGE}_{2}$ synthesis at 24 hours by basal HUVECs and HUVECs stimulated by $1 \mu \mathrm{M} \mathrm{PdBu}$ was used as a measure of COX-1 and COX-2 activity respectively as described previously. ${ }^{32}$ Both SC-560 and NS-398 inhibited PGE syn- $_{2}$ thesis by both COX isoforms at high concentrations (fig 2). A concentration of $3 \times 10^{-7} \mathrm{M}$ of both SC-560 and NS-398 was chosen for use in subsequent HuGE cell experiments. At this concentration, SC-560 and NS-398 selectively inhibited endothelial cell COX-1 and COX-2 activity respectively (fig 2 ).

BASAL COX EXPRESSION BY MONOLAYERS OF HuGE CELLS

HuGE cells expressed COX-1 mRNA and protein constitutively when cultured on $1 \%$ gelatin (figs $1 \mathrm{~B}, 3$, and 4). Under basal conditions, HuGE cells did not express COX-2 protein detectable by western analysis (fig 1B) although COX-2 mRNA was detected by RT-PCR (fig 3) and some specific cytoplasmic staining for COX-2 was shown by indirect immunofluorescence (fig 4).

EFFECT OF PLATING HuGE CELLS ON MATRIGEL: TUBE FORMATION AND COX EXPRESSION

HuGE cells formed circles of interlinking, tubular structures within two to four hours of plating onto basement membrane matrix (fig 5), which persisted at 24 hours. This has been described previously by us using HuGE cells ${ }^{13}$ and others with HUVECs. ${ }^{33}$ HuGE cell number and viability remained unchanged at 24 hours $\left(2 \times 10^{5}\right.$ cells/well; greater than $95 \%$ viability). Expression of COX-2 mRNA (and to

\section{$\mathrm{PdBu}$}
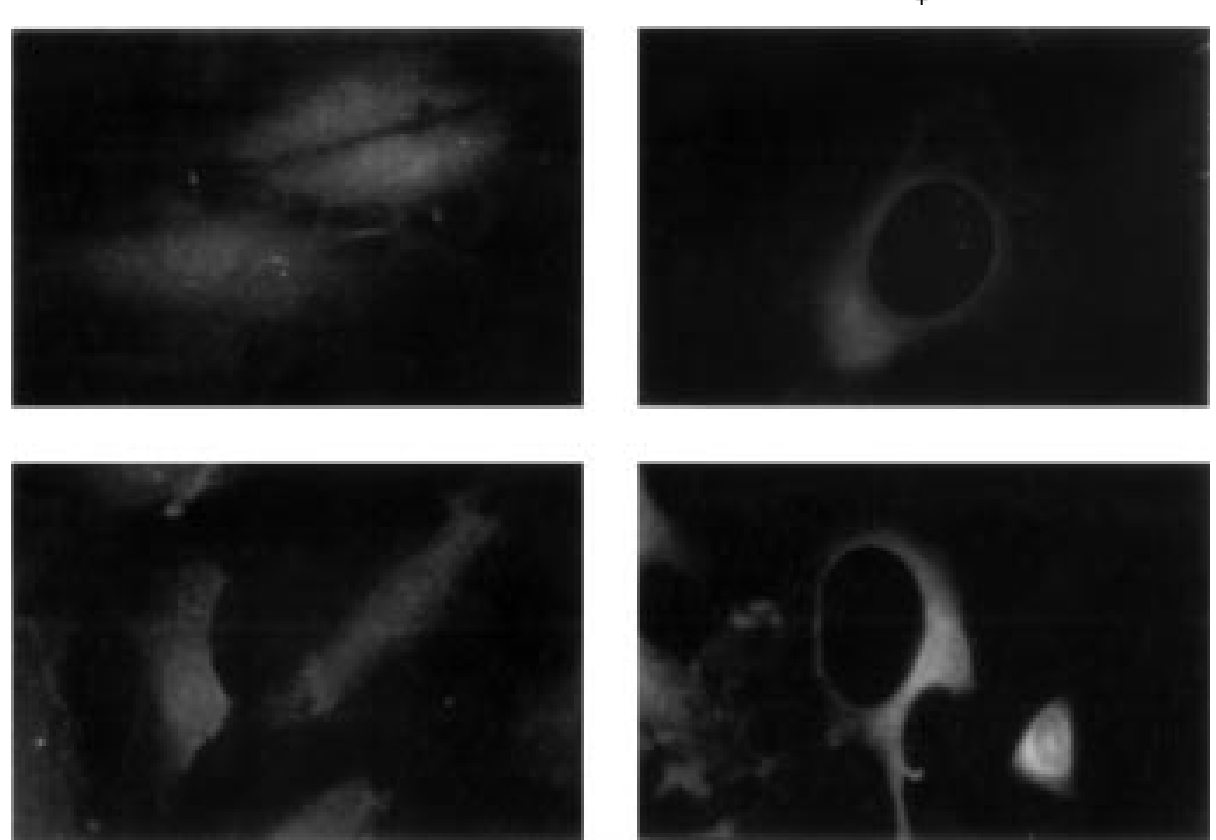

Figure 4 Indirect immunofluorescence studies of cyclooxygenase (COX) 1 and COX-2 expression by human gastric endothelial ( $\mathrm{HuGE}$ ) cells before and four hours after stimulation by $1 \mu \mathrm{M}$ phorbol 12,13-dibutyrate (PdBu). Control slides showed no specific staining. There was increased cytoplasmic COX-2 staining after incubation with PdBu with notable perinuclear staining. 

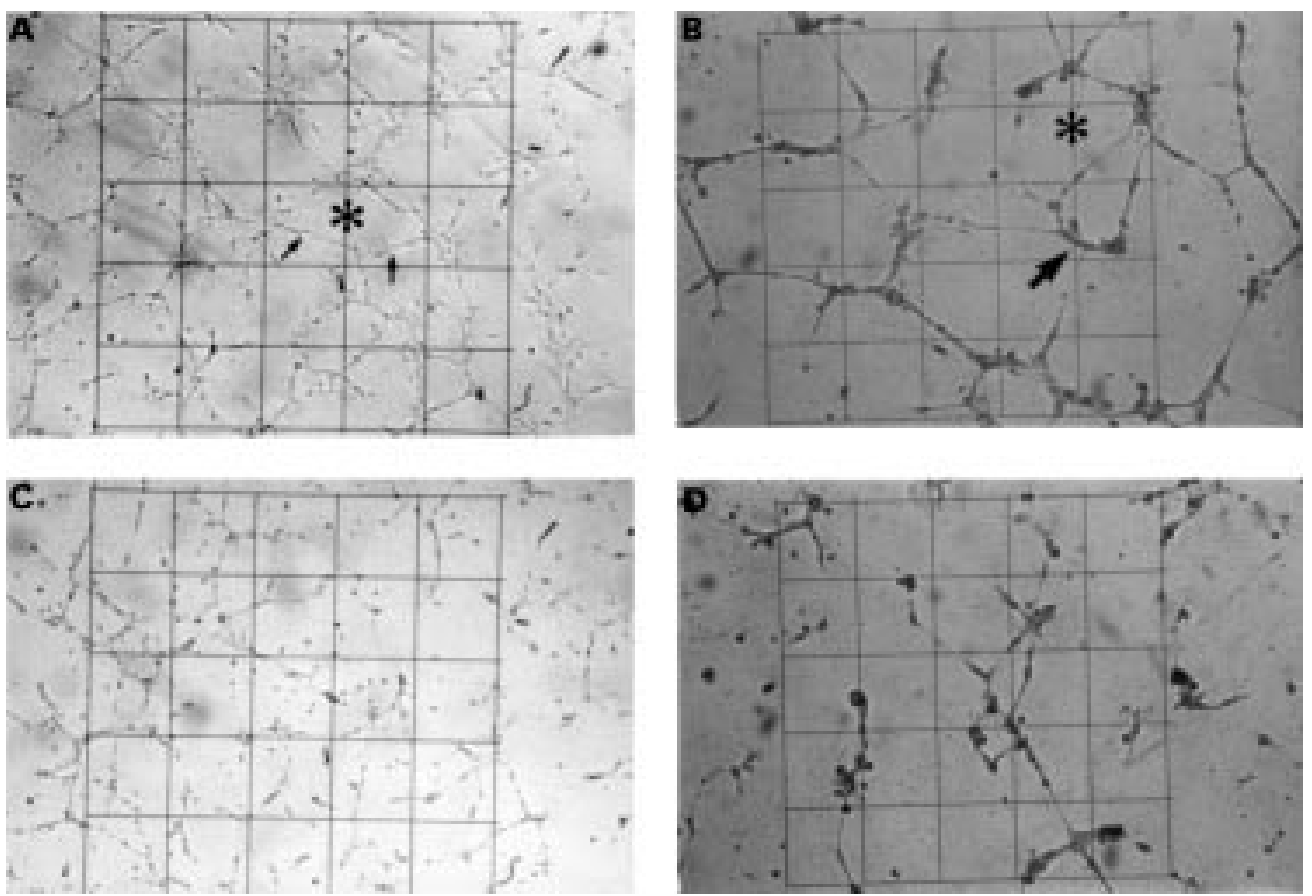

Figure 5 Formation of tubular structures by human gastric endothelial (HuGE) cells after plating onto thin gels of basement membrane matrix. Interlinking, tubular HuGE cells (arrows) on the gel surface formed circular structures (asterisk) under control conditions at four hours (A) and 24 hours (B) and in the presence of $3 \times 10^{-7} \mathrm{M} \mathrm{NS}-398$ at four hours (C) and 24 hours (D). The presence of NS-398 was associated with disruption of tubular structure formation by $H u G E$ cells resulting in a decrease in the number of circular structures (see also fig 7).

a lesser extent COX-1) by HuGE cells was increased at four and 24 hours after plating onto basement membrane matrix compared with cells replated onto $1 \%$ gelatin (fig 3 ). The amount of basement membrane matrix required to harvest sufficient HuGE cells for western blot analysis of COX protein precluded this experiment but increased functional COX-2 protein expression was confirmed by increased $\mathrm{PGE}_{2}$ production which was significantly inhibited by NS-398 but not SC-560 at four hours (fig 6). By contrast, NS-398 did not significantly inhibit $\mathrm{PGE}_{2}$ production by HuGE cells on basement membrane matrix at 24 hours (fig 6).

HUGE CELL MORPHOLOGY AND COX EXPRESSION FOLLOWING PHORBOL ESTER STIMULATION

There was significant non-specific staining of basement membrane matrix by COX-1 and COX-2 antibodies. Therefore, the phenotypic changes in HuGE cells induced by phorbol ester, namely intracellular vacuole formation and appearance of long cellular processes (fig 4), were used as an alternative model of angiogenesis for western blot analysis and indirect immunofluorescence studies. ${ }^{34}{ }^{35}$ Addition of 1 $\mu \mathrm{M} \mathrm{PdBu}$ induced COX-2 protein expression by HuGE cells at four and 24 hours (fig 1B) but there was no change in immunoreactive COX-1 protein expression. Indirect immunofluorescence studies carried out on HuGE cells after four hours incubation with $\mathrm{PdBu}$ showed that increased COX-2 staining remained cytoplasmic but with additional strong perinuclear staining (fig 4).
EFFECT OF NS-398 ON HuGE CELL ANGIOGENESIS IN VITRO

Having shown induction of functional COX-2 expression by HuGE cells in two in vitro models of angiogenesis, we investigated the effect of the selective COX-2 inhibitor, NS-398 on tubular structure formation by HuGE cells on

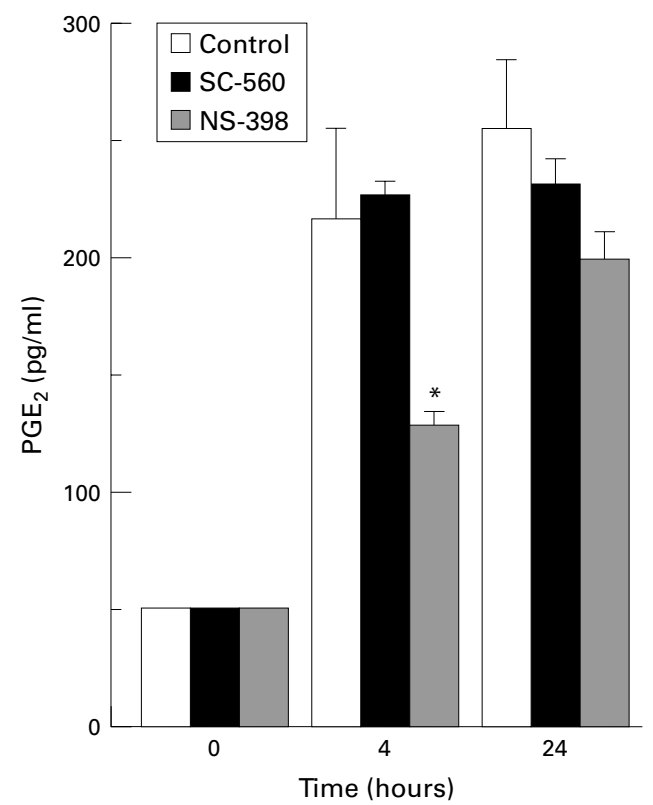

Figure 6 Prostaglandin (PG) $E_{2}$ synthesis by human gastric endothelial (HuGE) cells plated on basement membrane matrix. SC-560 and NS-398 were used at $3 \times$ $10^{-7} \mathrm{M}$. Results are expressed as the mean (SEM) $P G E_{2}$ level $(n=4)$. There was significant inhibition of $P G E_{2}$ synthesis by NS-398 but not SC-560 during tubular structure formation by $\mathrm{HuGE}$ cells at four hours. ${ }^{\star} p=0.05$ (Kruskal-Wallis one way ANOVA). 


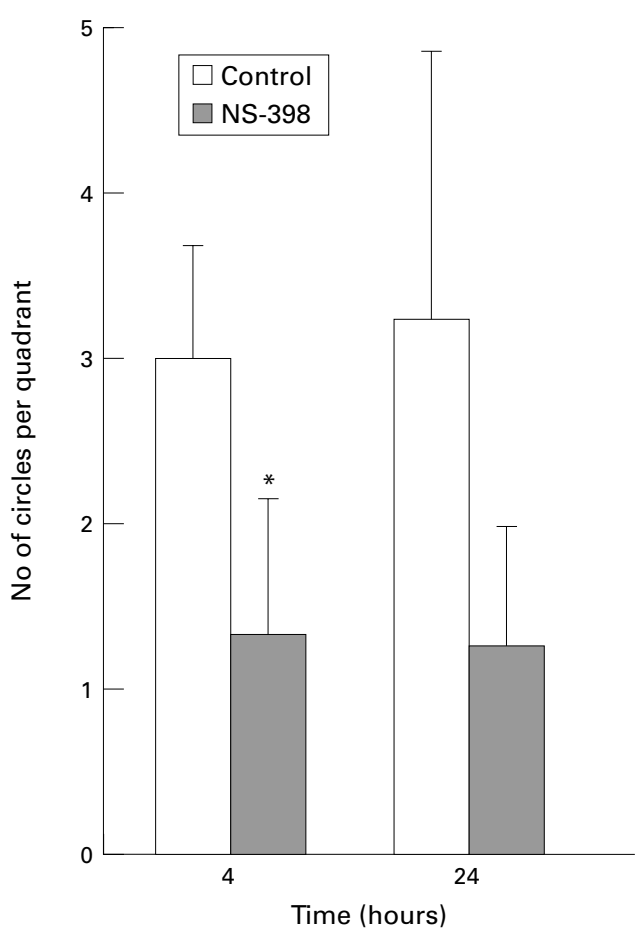

Figure 7 Effect of NS-398 $\left(3 \times 10^{-7} \mathrm{M}\right)$ on tubular structure formation by human gastric endothelial (HuGE) cells on basement membrane matrix. Results are expressed as the number of circles (made up of interlinking tubular $H u G E$ cells) per quadrant of a six well plate well $(n=8$, four hours; $n=4,24$ hours). NS-398 treatment was associated with a significant decrease in circle formation by tubular HuGE cells at four hours. ${ }^{\star} p=0.05$

(Mann-Whitney $U$ test).

basement membrane matrix using a quantitative assay (fig 5). The majority of tubular structure formation by HuGE cells occurred during the first four hours after plating onto basement membrane matrix with little increase in the number of circles of interlinking, tubular structures up to 24 hours (fig 7). NS-398 ( $3 \times$ $\left.10^{-7} \mathrm{M}\right)$ significantly inhibited formation of circles of interlinking, tubular structures by HuGE cells at four hours compared with control conditions $(p=0.05$, Mann-Whitney U test; figs 5 and 7). The effect of NS-398 on tubular structure formation by HuGE cells was less pronounced at 24 hours (fig 7). NS-398 did not effect HuGE cell number or viability up to 24 hours.

\section{Discussion}

We have shown that unstimulated $\mathrm{HuGE}$ cells express COX-1 and low levels of COX-2 in vitro. HuGE cells required the presence of $30 \%$ fetal calf serum for continued growth and did not tolerate serum free conditions or $0.5 \%$ serum so we cannot rule out slight induction of COX-2 by serum factors which has been shown in HUVECs. ${ }^{32}$ Low level COX-2 expression by unstimulated HUVECs has been previously reported using RT-PCR ${ }^{15}$ but Morita et al were unable to detect COX-2 in HUVECs and bovine aortic endothelial cells grown in the presence of $10 \%$ serum by indirect immunofluorescence. ${ }^{16}$

It has recently been reported that human intestinal microvascular endothelial cells express inducible cytokines such as interleukin 8 constitutively. ${ }^{19}$ With the caveat discussed above, our data suggest that a similar situation exists for COX-2 as well as for COX-1 in HuGE cells. Currently, there are no published data on endothelial cell COX expression in the gastrointestinal tract except for a report by Mikkelsen et al who showed immunoreactivity in endothelial cells throughout the human intestine using a non-specific anti-COX antibody which probably recognised both COX isoforms. ${ }^{36}$ Even though basal PG production by HuGE cells in vitro is low, the vast number of HuGE cells comprising the dense mucosal capillary network of the stomach in humans ${ }^{37}$ may mean that endothelial cells are an important source of human gastric mucosal PGs in vivo as has been shown in canine gastric mucosa. ${ }^{12}$ Constitutive COX-2 expression by gastric endothelial cells may explain the ability of a specific COX-2 inhibitor to abrogate the protective effect of $20 \%$ ethanol on subsequent $70 \%$ ethanol induced gastric injury in rats. ${ }^{38}$

We have shown that HuGE cell angiogenesis is associated with induction of functional COX-2 expression using basement membrane matrix and phorbol ester models. Basement membrane matrix is well established as a model of angiogenesis. The capillary like network produced one to two hours after plating of endothelial cells onto basement membrane matrix consists of tubular structures which contain a lumen surrounded by endothelial cells. ${ }^{39}$ Phorbol esters are angiogenic in vivo ${ }^{40}$ and in vitro. ${ }^{34}$ The morphological changes induced by phorbol esters are dependent on the type of gel on which the endothelial cells are plated. Formation of long cell processes by bovine microvascular endothelial cells and HUVECs on plastic after incubation with phorbol ester similar to that seen by HuGE cells has been reported previously. ${ }^{3441}$ Intracellular vacuole formation, which is believed to be an early stage of lumen development, has previously been described in human foreskin capillary endothelial cells. ${ }^{42}$ Induced COX-2 protein in HuGE cells was predominantly perinuclear, which is similar to the localisation previously reported in HUVECs. ${ }^{16}$

Induction of COX-2 expression in HUVECs via protein kinase $\mathrm{C}$ (PKC) activation is well recognised. ${ }^{15}$ The formation of tubular structures by HUVECs on basement membrane matrix is also dependent on activation of PKC. ${ }^{43}$ It seems likely that basement membrane matrix may also, at least in part, induce COX-2 expression and angiogenesis by HuGE cells via this pathway. In our experiments, phorbol ester and basement membrane matrix both caused similar morphological changes and both induced COX-2 expression. Identifying which components of basement membrane promote angiogenesis and COX expression and elucidating the signalling pathways involved are important because of the central involvement of angiogenesis in ulcer healing and the adverse impact of NSAIDs on both these processes.

Having shown induction of functional COX-2 expression by HuGE cells during angiogenesis in vitro, we confirmed a causal role 
for COX-2 during HuGE cell angiogenesis on basement membrane matrix using a quantitative tubular structure formation assay similar to those described previously. ${ }^{34}{ }^{44}{ }^{45}$ NS-398, at a concentration which selectively inhibited endothelial cell COX-2 function, significantly attenuated HuGE cell tubular structure formation at four hours. At 24 hours, the effect of NS-398 on tubular structure formation and $\mathrm{PGE}_{2}$ production by HuGE cells was less pronounced. A possible explanation for the relative lack of effect of selective COX-2 inhibition at 24 hours, despite continuing upregulation of COX-2 mRNA by HuGE cells on basement membrane matrix, is lack of sufficient arachidonic acid substrate for COX-2 function. It has been shown that COX-1 and COX-2 utilise different pools of arachidonic $\operatorname{acid}^{46}$ and it is possible that, at 24 hours, there is a lack of arachidonic acid available for COX-2 because of pool exhaustion or diversion to COX-1.

Tsujii et al have previously reported the effect of coculture of colorectal cancer cells with HUVECs on tubular structure formation and COX expression by HUVECs plated on thick type I collagen gels. ${ }^{47}$ Tubular structure formation by HUVECs was associated with induction of COX-1 and COX-2 expression. Importantly, it was shown that a COX-1 (but not COX-2) antisense oligonucleotide inhibited angiogenesis in this model of tumour angiogenesis. ${ }^{47}$ The differences between the study of Tsujii et $a l^{47}$ and the results reported here could be explained by endothelial cell specific differences in COX expression or the possibility that different substrates induce tubular structure formation by endothelial cells via different pathways which involve either or both COX isoforms. Otherwise there are few existing reports of the effect of COX inhibition by NSAIDs and exogenous PGs on angiogenesis. Several NSAIDs have been shown to reduce angiogenesis and growth of tumours in rats. ${ }^{48}$ Conversely, $\mathrm{PGE}_{1}$ and $\mathrm{PGE}_{2}$ promote angiogenesis in vivo. ${ }^{49-51}$ Decreased granulation tissue vascularity has been reported in experimental gastric ulcers in rats administered NSAIDs $^{822}$ and in NSAID associated gastric ulcers in humans. ${ }^{20}$ However, these studies do not neccessarily imply a direct role for COX expression in gastric ulcer angiogenesis as NSAIDs could be acting directly on angiogenesis via a non-COX dependent mechanism or indirectly by altering expression of angiogenic factors by other granulation tissue cells such as macrophages and fibroblasts.

In summary, the data presented in this paper show that, under normal culture conditions, HuGE cells express both COX-1 and COX-2 in vitro. We have also shown that induction of COX-2 expression is associated with angiogenesis by HuGE cells in two in vitro models and that COX-2 plays a role in $\mathrm{HuGE}$ cell angiogenesis on basement membrane matrix.

The role of each COX isoform in human gastric ulcer granulation tissue angiogenesis in vivo remains to be elucidated. It has been shown that the selective COX-2 inhibitor, L-745,337, reduces granulation tissue vascularity and delays healing of cryoprobe induced gastric ulcers in rats to the same extent as the non-selective COX inhibitors, indomethacin and diclofenac. ${ }^{8}$ In the light of our data showing the role of COX-2 expression during angiogenesis by HuGE cells in vitro, further studies are warranted to investigate whether selective COX-2 inhibitors impair granulation tissue angiogenesis and delay gastric ulcer healing in humans.

J L Thomson was supported by a grant from the Trent Research Scheme.

1 Eberhart CE, DuBois RN. Eicosanoids and the gastrointestinal tract. Gastroenterology 1995;109:285-301.

2 Hawkey CJ, Rampton DS. Prostaglandins and the gastrointestinal mucosa: are they important in its function, disease, or treatment? Gastroenterology 1985;89:1162-88.

3 Silverstein FE, Graham DY, Senior JR, et al. Misoprostol reduces serious gastrointestinal complications in patients with rheumatoid arthritis receiving nonsteroidal antiinflammatory drugs. A randomized, double-blind, placebocontrolled trial. Ann Intern Med 1995;123:241-9.

4 Williams CS, Smalley W, DuBois RN. Aspirin use and potential mechanisms for colorectal cancer prevention. $\mathcal{F}$ Clin Invest 1997;100:1325-9.

5 Frolich JC. Prostaglandin endoperoxide synthetase isoenzymes: the clinical relevance of selective inhibition. Ann Rheum Dis 1995;54:942-3.

6 O'Neill GP, Ford-Hutchinson AW. Expression of mRNA for cyclooxygenase-1 and cyclooxygenase-2 in human tissues. FEBS Lett 1993;330:156-60.

7 Mizuno H, Sakamoto C, Matsuda K, et al. Induction of cyclooxygenase 2 in gastric mucosal lesions and its inhibition by the specific antagonist delays healing in mice. Gastroenterology 1997;112:387-97.

8 Schmassmann A, Peskar BM, Stettler C, et al. Effects of inhibition of prostaglandin endoperoxide synthase-2 in chronic gastro-intestinal ulcer models in rats. Br F Pharmacol 1998;123:795-804.

9 Ferraz JG, Sharkey KA, Reuter BK, et al. Induction of cyclooxygenase 1 and 2 in the rat stomach during endotoxaemia: role in resistance to damage. Gastroenterology 1997;113:195-204.

10 Iseki S. Immunocytochemical localization of cyclooxygenase-1 and cyclooxygenase-2 in the rat stomach. Histochem $\mathcal{F}$ 1995;27:323-8.

11 Kargman S, Charleson S, Cartwright M, et al. Characterization of prostaglandin $\mathrm{G} / \mathrm{H}$ synthase 1 and 2 in rat, dog, monkey, and human gastrointestinal tracts. Gastroenterology 1996;111:445-54

12 Chen MC, Sanders MJ, Amirian DA, et al. Prostaglandin $\mathrm{E}_{2}$ production by dispersed canine fundic mucosal cells; contribution of macrophages and endothelial cells as major sources. F Clin Invest 1989;84:1536-49.

13 Hull MA, Hewett PW, Brough JL, et al. Isolation and culture of human gastric endothelial cells. Gastroenterology 1996; 111:1230-40.

14 Maier JA, Voulalas P, Roeder D, et al. Extension of the lifespan of human endothelial cells by an interleukin-1 $\alpha$ antispan of human endothelial cells by an intert

15 Hense oligomer. Science $1990 ; 249: 1570-4$. Natl Acad Sci USA 1992;89:7384-8.

16 Morita I, Schindler M, Regier MK, et al. Different intracellular locations for prostaglandin endoperoxide $\mathrm{H}$ synthase-1 and -2. F Biol Chem 1995;270:10902-8.

17 Zembowicz A, Jones SL, Wu KK. Induction of cyclooxygenase- 2 in human umbilical vein endothelial cells by lysophosphatidylcholine. F Clin Invest 1995;96: 1688-92.

18 Gerritsen ME. Functional heterogeneity of vascular endothelial cells. Biochem Pharmacol 1987;36:2701-11.

19 Nilsen EM, Johansen F-E, Jahnsen FL, et al. Cytokine profiles of cultured microvascular endothelial cells from the human intestine. Gut 1998;42:635-42.

20 Hudson N, Balsitis M, Everitt S, et al. Angiogenesis in gastric ulcers; impaired in patients taking non-steroidal gastric ulcers; impaired in patients taking no
anti-inflammatory drugs. Gut 1995;37:191-4.

21 Lancaster-Smith MJ, Jaderberg MR, Jackson DA. Ranitidine in the treatment of non-steroidal anti-inflammatory drug associated gastric and duodenal ulcers. Gut 1991;32: 252-6.

22 Schmassmann A, Tarnawski A, Peskar BM, et al. Influence of acid and angiogenesis on kinetics of gastrtic ulcer healing in rats: interaction with indomethacin. Am f Physiol 1995; 268: G276-85.

23 Jaffe EA, Nachman RL, Becker CG, et al. Culture of human endothelial cells derived from umbilical veins: identification by morphologic and immunologic criteria. 7 Clin Invest 1973;52:2745-56.

24 Kleinman HK, McGarvey ML, Hassell JR, et al. Basement membrane complexes with biological activity. Biochemistry 1986;25:312-18.

25 Chomczynski P, Sacchi N. Single-step method of RNA isolation by acid guanidium thiocyanate-phenol-chloroform extraction. Anal Biochem 1987;162:156-9. 
26 Harris RC, McKanna JA, Akai Y, et al. Cyclooxygenase-2 is associated with the macula densa of rat kidney and increses with salt restriction. 7 Clin Invest 1994;94:250410.

27 Vane JR, Mitchell JA, Appleton I, et al. Inducible isoforms of cyclooxygenase and nitric oxide synthase in inflammation Proc Natl Acad Sci USA 1994;91:2046-50.

28 Zhang F, Warskulat U, Wettstein M, et al. Identification of betaine as an osmolyte in rat liver macrophages (Kupffer cells). Gastroenterology 1996;110:1543-52.

29 Hull MA, Brough JL, Powe DG, et al. Expression of basic fibroblast growth factor in intact and ulcerated human gastric mucosa. Gut 1998;43:525-36.

30 Futaki N, Takahashi S, Yokohama M, et al. NS-398, a new anti-inflammatory agent, selectively inhibits prostaglandin $\mathrm{G} / \mathrm{H}$ synthase/cyclooxygenase (COX-2) activity in vitro. Prostaglandins 1994;47:55-9.

31 Smith CJ, Zhang Y, Koboldt CM, et al. Pharmacological analysis of cyclooxygenase- 1 in inflammation. Proc Natl Acad Sci USA 1998;95:13313-18.

32 Habib A, Creminon C, Frobert Y, et al. Demonstration of an inducible cyclooxygenase in human endothelial cells using
antibodies raised against the carboxyl-terminal region of antibodies raised against the carboxyl-terminal region

33 Madri JA, Pratt BM. Endothelial cell-matrix interactions: in vitro models of angiogenesis. I Histochem Cytochem 1996;34:85-91.

34 Montesano RA, Orci L. Tumor-promoting phorbol esters induce angiogenesis in vitro. Cell 1985;42:469-77.

35 Montesano RA, Orci L. Phorbol esters induce angiogenesis in vitro from large vessel endothelial cells. F Cell Physiol 1987;130:284-91.

36 Mikkelsen HB, Rumessen JJ, Qvortrup K. Prostaglandin H synthase immunoreactivity in human gut. An immunohistochemical study. Histochemistry 1991;96:295-9.

37 Gannon B, Browning J, O'Brien P, et al. Mucosal microvascular architecture of the fundus and body of human stomach. Gastroenterology 1984;86:866-75.

38 Gretzer B, Ehrlich K, Maricic N, et al. Selective cyclooxygenase-2 inhibitors and their influence on the protective
effect of a mild irritant in the rat stomach. Br 7 Pharmacol 1998;123:927-35.
39 Kubota Y, Kleinman HK, Martin GR, et al. Role of laminin and basement membrane in the morphological differentiaand basement membrane in the morphological differentia-
tion of human endothelial cells into capillary-like structures. F Cell Biol 1988;107:1589-98.

40 Morris PB, Hida T, Blackshear PJ, et al. Tumor-promoting phorbol esters induce angiogenesis in vivo. Am $\mathcal{F}$ Physiol 1988;254:C318-22.

41 Antonov AS, Lukashev ME, Romanov YA, et al. Morphoogical alterations in endothelial cells from human aorta and umbilical vein induced by forskolin and phorbol 12-myristate 13-acetate: a synergistic action of adenylate cyclase and protein kinase C activators. Proc Natl Acad Sci USA 1986;83:9704-8.

42 Folkman J, Haudenschild C. Angiogenesis in vitro. Nature 1980;288:551-6.

43 Kinsella JL, Grant DS, Weeks BS, et al. Protein kinase C regulates endothelial cell tube formation on basement
membrane matrix, Matrigel. Exp Cell Res 1992;199:56-62.

44 Gamble JR, Matthias LJ, Meyer G, et al. Regulation of in vitro capillary tube formation by anti-integrin antibodies. $\mathcal{F}$ Vell Biol 1993;121:931-43.

45 Grant DS, Tashiro K-I, Segui-Real B, et al. Two different laminin domains mediate the differentiation of human endothelial cells into capillary-like structures in vitro. Cell 1989;58:933-43.

46 Reddy ST, Herschman HR. Ligand-induced prostaglandin synthesis requires expression of the TIS10/PGS-2 prostaglandin synthase gene in murine fibroblasts and macrophages. F Biol Chem 1994;269:15473-80.

47 Tsujii M, Kawano S, Tsuji S, et al. Cyclooxygenase regulates angiogenesis induced by colon cancer cells. Cell 1998;93: 705-16.

48 Peterson H-I. Effects of prostaglandin synthesis inhibitors on tumor growth and vascularization. Invasion Metastasis 1983;3:151-9.

49 Benezra D. Neovasculogenic ability of prostaglandins, growth factors, and synthetic chemoattractants. $\mathrm{Am} \mathcal{F}$ growth factors, and synthe

50 Ziche M. Jones J, Gullino PM. Role of prostaglandin $\mathrm{E}_{1}$ and copper in angiogenesis. 7 Natl Cancer Inst 1982;69:475-82.

51 Form DM, Auerbach R. PGE 2 and angiogenesis. Proc Soc Exp Biol Med 1983;172:214-18. 